UDK: 343.85:314.151.3-054.73(438) 343.343.62(438)

doi:10.5937/crimen2001034P

ORIGINALNI NAUČNI RAD

PRIMLJEN / PRIHVAĆEN: 19. 2. 2020. / 15. 3. 2020.

Magdalena Perkowska*

\title{
POLISH RESPONSE TO ILLEGAL BORDER CROSSING
}

\begin{abstract}
The main aim of this article is to present the threat to the security Polish borders caused by the illegal border crossing. As Poland is found as a bridge between Eastern and Western Europe author wants to verify the scale of illegal border crossing in the last six years. This period includes also the migration crisis. Another issue that is analysed is the criminal law response to illegal border crossing and to the arrangement of illegal border crossing. Article presents Polish criminal law regulations in this area considering also the influence of European Union regulations. The last part refers to the penalties pronounced to those who crossed borders illegally and to those who arranged the illegal border crossing for the others.
\end{abstract}

Key words: illegal migration, illegal border crossing, criminal policy.

\section{INTRODUCTION}

Poland is centrally situated in the European continent. Its geographical location determines the course of illegal migration routes through its territory. Currently, these lead from Vietnam through Russia and the Baltic states to Poland (so called Baltic route); from Russia through Ukraine or Belarus to Poland and further through Germany to other Western European countries. Or from conflict areas such as Syria and Iraq through Turkey, Greece, North Macedonia, the former Yugoslavia, Hungary, Austria, the Czech Republic to Poland and thence to Germany or the Scandinavian countries. ${ }^{1}$

The main factors which influence illegal migration to and through Poland, are its EU membership as well as its status as a Schengen state. Migrants assume that by entering Poland or the Baltic states located in the Schengen area, they will be able to move freely around Europe, especially going further west. The simplest way of

\footnotetext{
* Assistant Professor, Faculty of Law, University of Bialystok, m.perkowska@uwb.edu.pl.

1 K. von Lampe /2005/: Organised Crime in Europe - in: Handbook of Transnational Crime and Justice (P. Reichel, ed.), London, New Dehli, p. 411; Europol /2016/: Migrant smuggling in the EU, p. 5; Europol /2017/: European Union serious and organised crime threat assessment. Crime in the age of technology, p. 49.
} 
illegal migration is the illegal border crossing through or between the border check points. This is why the aim of this article is to present the position of Polish borders in the migration situation in EU and the threat posed by illegal border crossing. The second part will refer to the legal grounds of criminal responsibility for illegal border crossing and for arrangement of illegal border crossing. Those legal provisions will be compared with the courts reaction to this illegal behaviour. This reaction will be analysed on the base of general information on pronounced penalties from the Ministry of Justice.

\section{ILLEGAL BORDER CROSSING - STATISTICAL PRESENTATION}

There are eight established routes of illegal migration leading to the EU: Central Mediterranean, Eastern Mediterranean, Western Balkan, Circular from Albania to Greece, Western Mediterranean, Eastern borders, Black Sea and Western African. $^{2}$ The land route, which is described as the Eastern land or Eastern borders route, runs to the EU through Estonia, Finland, Latvia, Lithuania, Poland, Slovakia, Hungary and Romania; this route in 2015 was exploited by nationals from Afghanistan, Vietnam, Georgia and Syria ${ }^{3}$. In 2015 migrants started to use a new, so-called Arctic route, which runs from Russia to Norway and Finland. Since 2016 there were mostly nationals from Vietnam, Ukraine and Russia detected ${ }^{4}$. The Eastern land border in 2018 saw an approximately $24 \%$ increase in detections compared with 2017, partly due to migrants abusing the FIFA Fan ID, which allowed travellers visafree entry to Russia, from where, coming also via Belarus and Ukraine, the migrants attempted to enter the EU illegally. With a share of around $34 \%$, Vietnamese nationals represented an even larger portion of illegal border-crossings at the Eastern Land Border route compared to 2017, followed at a distance by Iraqis, Russians and Ukrainians ${ }^{5}$.

Despite the total length of all the border sections $(6000 \mathrm{~km})$, detections on this route tend to be lower than on other routes, possibly due to the long distances between major hubs and many countries of origin. Also, according to several reports published in 2014, visa fraud and counterfeit border crossing stamps tend to be a dominant modus operandi on this route, as opposed to detections of illegal border crossing. Detections of illegal border crossing remained decreasing, with 1,275 detections in 2014 and 1,084 in 2018. Most detections were reported at the land border between Lithuania and Belarus. Most of these detections were of Vietnamese nationals arriving after transiting through Belarus. By contrast to other routes, large proportions of these detections (concerning Russian Ukrainian nationals) were connected with the smuggling of goods rather than illegal migration. Regarding the

2 Frontex /2016/: Risk Analysis for 2015, Warsaw, p. 15.

3 Frontex, ibid., p. 17.

4 Frontex, ibid., p. 19.

5 Frontex /2019/: Risk Analysis for 2018, Warsaw, p. 17. 
border with Ukraine, Frontex monitors the situation, but since 2014 no important changes were noticed. Detections for illegal border crossing remain insignificant along all green border sections with the Ukraine and the number of refusals of entry remained comparable to previous years. ${ }^{6}$

The state border of the Republic of Poland is $3511.52 \mathrm{~km}$ long: $232.04 \mathrm{~km}$ of which is with the Russian Federation; ${ }^{7} 104.28 \mathrm{~km}$ with the Republic of Lithuania; $418.24 \mathrm{~km}$ with the Republic of Belarus and $535.18 \mathrm{~km}$ with Ukraine; $541.06 \mathrm{~km}$ with the Slovak Republic; $796.04 \mathrm{~km}$ with the Czech Republic; and $489.37 \mathrm{~km}$ with the Federal Republic of Germany. ${ }^{8}$ The sea border amounts to $439.74 \mathrm{~km}$. The Polish section of the EU internal border is $1930.62 \mathrm{~km}$, whereas the Polish section of the EU external border is $1580.77 \mathrm{~km}$; thus the Polish section of the external EU border constitutes one quarter of the whole Eastern land route. Polish borders are a part of Eastern borders route. These are the external borders with Belarus and Ukraine and Russian Federation - Kaliningrad Oblast. It is worth to remind that there is small border section with Lithuania, which is he internal EU border situated between to external border section (with Russian Federation - Kaliningrad Oblast and with Belarus).

The data provided in Table 1 on the number of persons apprehended after having crossed the border of the Republic of Poland illegally acts as an indicator of the so-called 'migration pressure'. The data of the Border Guards concerning the persons apprehended encompass all cases of illegal border crossing, not just illegal border crossing between border check points. These data (apart from the data concerning, for example, the number of refusals on entry and the number of illegal stays) are, however, difficult to interpret, as they do not indicate the scale of illegal migration, but, rather, the efficiency of the actions taken by various services. Moreover, the number of foreigners who legalise their stay within the framework of abolition (for foreigners who had been staying in Poland illegally) or other mechanisms which allow them to regulate their legal status is a crucial indicator demonstrating the scale of illegal migration in Poland. ${ }^{9}$

Based on data provided by the Border Guard there are different forms illegal border crossing that have been identified by law enforcement authorities and, above all, by the Border Guard.

6 Frontex /2015/: Risk Analysis for 2014, Warsaw, pp. 24-25; M. Perkowska /2017/: Charakterystyka przestępczości granicznej cudzoziemców w Polsce na podstawie wyników badań akt spraw karnych - in: Przestępczość cudzoziemców. Aspekty prawne, kryminologiczne i praktyczne (W. Klaus, K. Laskowska, I. Rzeplińska, eds.), Warszawa, pp. 59-75; M. Perkowska /2018/: The Impact of the Migration Crisis on Polish Immigration and Criminal Law - in: Irregular Migration as a Challenge for Democracy (E. Kużelewska, A. Weatherburn, D. Kloza, eds.), Cambridge-Antwerp-Portland, p.196.

7 Covering the section which divides the territorial sea of the Republic of Poland and the Russian Federation $-22.21 \mathrm{~km}$.

8 Covering the section which divides the territorial sea of the Republic of Poland and the Federal Republic of Germany - $22.22 \mathrm{~km}$.

9 Ministerstwo Spraw Wewnętrznych i Administracji Departament Polityki Migracyjnej /2011/: Polityka Migracyjna Polski - stan obecny i postulowane działania, Warszawa, p. 40. 
Unlawful entry (at the so-called green border, between border check-points), in the case of Poland, refers to the land border and, as indicated by the Border Guard, takes place mainly with the participation of organised criminal groups. Rarely do migrants attempt to reach the destination country individually and independently. This form of illegal migration poses a constant threat to Poland's borders with Belarus and Ukraine. The Lithuanian section of the border, which is an internal EUSchengen border is also exploited as the risk of detection at border control is much lower. The Baltic sea route is rarely used and mainly concerns outbound travel from Poland to Sweden. ${ }^{10}$

Air routes are also used but this method requires possessing the appropriate documents. In such cases, foreigners invariably use false identity documents of other EU states and present themselves as being nationals of those countries (e.g. Austria, France, Italy). They also use original travel documents and visas which are obtained on the basis of false documents. ${ }^{11}$

According to the Border Guard's data, most forgeries concern visas and border control stamps. The latter are changed in order to confirm the 'legality' of periods of stay within the EU and to obtain a new visa ${ }^{12}$. To achieve this, a foreign national whose period of stay has expired simply changes the date in the border control stamp so that the length of stay complies with the visa conditions for the application of a new visa. Aside from the above mentioned documents, passports, residence permits and identity documents are also falsified.

Foreigners also use authentic documents which belong to another person. This is the so-called 'look alike' method. ${ }^{13}$ The original document is usually the product of theft or is ceded by the person to whom it was issued. Another offence is visa fraud. To the greatest extent, foreigners commit visa fraud in Polish consulates, but there have also been instances of this malpractice occurring in the consulates of other EU states, such as the Czech Republic, Germany, Estonia, Greece, Lithuania, the Netherlands and Slovenia, and they mostly involved Polish visas. Such visas were chiefly issued in Lviv, Vinnitsa and Lutsk and the perpetrators were mainly intercepted at the Polish sections of the EU/Schengen internal border (with Germany, the Czech Republic and Slovakia). ${ }^{14}$

The phenomenon of visa fraud, which authorise foreigners to enter and stay in the Schengen area, is accompanied by the development of economic entities run by both Polish citizens and foreigners, who participate in its organisation and facilitation. A system of intermediaries is also active in order to obtain visas and/or other documents confirming the purpose of the trip, both false and authentic ones such

10 Ministerstwo Spraw Wewnętrznych i Administracji /2014/: Raport o stanie bezpieczeństwa w Polsce w 2013 roku, Warszawa, pp. 111-112.

11 Ministerstwo Spraw Wewnętrznych i Administracji /2014/, ibid.

12 Ministerstwo Spraw Wewnętrznych i Administracji /2012/: Raport o stanie bezpieczeństwa w Polsce w 2011 roku, Warszawa, pp. 115.

13 Ministerstwo Spraw Wewnętrznych i Administracji /2014/, op.cit., p. 112.

14 Ministerstwo Spraw Wewnętrznych i Administracji /2015/: Raport o stanie bezpieczeństwa w Polsce w 2014 roku, Warszawa, p. 104. 
as work permits, invitations, documents confirming hotel reservations, return tickets, conference attendances or health services. ${ }^{15}$ Such entities also frequently issue invitations for business talks which in reality never take place. ${ }^{16}$ In that context, an employer's declaration of intent to employ a foreigner is the one most commonly used for illegal migration. ${ }^{17}$

In 2015, a new method was noticed in attempts by third country nationals to legalise their stay in Poland. Foreigners would arrive in the country using a false residency title of another EU state or a false visa (e.g. Spanish or Greek). In case of false visa, false stamps would be placed in passports to indicated that the foreigner had legally crossed an external border of the EU. On the basis of documents prepared in this way, foreigners applied for legalisation of their stay in Poland, and thus for obtaining a residence document on the basis of which they could move freely within the EU. If necessary, a fictitious residence registration (some citizens in Poland, each had several dozen of such registrations) or a fictitious professional career (the employment of a foreigner was most often recorded in the documents of one of the many front companies) was arranged. The procedure concerned mainly citizens of Pakistan and India, who had already exhausted all other possibilities of legalising their stay in the territory of other EU countries. On the initiative of Europol and in cooperation with the border services of Poland and Spain, the 29 suspected migrant smugglers were arrested. Those arrested are thought to be part of an organised crime network responsible for facilitating deadly journeys for Pakistani migrants across the Mediterranean Sea, as well as labour exploitation. ${ }^{18}$

Table 1. The number of people apprehended after having crossed the Polish borders illegally in 20014-2019

\begin{tabular}{|l|c|c|c|}
\hline Year & External border & Internal border & Total \\
\hline 2014 & 2124 & 2787 & 4911 \\
\hline 2015 & 3365 & 3615 & 6980 \\
\hline 2016 & 3525 & 4041 & 7566 \\
\hline 2017 & 3191 & 4094 & 7285 \\
\hline 2018 & 3486 & 2038 & 5524 \\
\hline 2019 & 3024 & 2164 & 5188 \\
\hline
\end{tabular}

Source: The Border Guard Headquarters http://strazgraniczna.pl/pl/granica/statystykisg/2206,Statystyki-SG.html

15 Ministerstwo Spraw Wewnętrznych i Administracji /2012/, op.cit., p. 114.

16 M. Perkowska /2017/, op.cit., p. 212.

17 Ministerstwo Spraw Wewnętrznych i Administracji /2014/, op.cit., p. 113.

18 Ministerstwo Spraw Wewnętrznych i Administracji /2016/: Raport o stanie bezpieczeństwa w Polsce w 2015 roku, Warszawa, p. 198; UNODC /2016/: Smuggling of migrants from Pakistan.

Reasons, routes and risks, p. 83. 
The number of people apprehended after having crossed the Polish borders illegally tend to increase until 2017. In 2018 a decrease was registered. The increase in 2015, could be easily attributed to the migration crisis. However, it was not the case. It was caused mainly by the influx of migrants (legal and illegal) leaving Ukraine due to military conflict with Russia (see Table 2.). ${ }^{19}$ According to the data presented in Table 3, the highest number of people who crossed or attempted to cross the Polish border illegally was recorded in 2016, but mainly at the internal border. ${ }^{20}$

When Poland joined the Schengen area in December 2007 it seems that there will be more detections on the Polish section of the EU external border. From now on Poland strengthened its position as a kind of bridge between the East and South and the West. ${ }^{21}$ Migrants wrongly presumed that crossing the Eastern border of Poland would enable them to smoothly reach any EU Member States. Simultaneously, it is worth highlighting that Poland is more often perceived as the country of destination, which may lead to the conclusions that it is becoming more attractive in terms of labour market, remuneration or life and social conditions. This is reflected in the following statistics: in the period 2001-2013 over 155.000 persons registered in Poland for permanent residence, and only in 2013 almost 81.000 foreigners abroad registered for a temporary stay in Poland. ${ }^{22}$

The increase in the number of suspect foreigners in 2015 could easily be attributed to the migration crisis in Europe, as the Border Guard has recorded more illegal border crossings or the use of forged documents. In 2014 the Border Guard detained 4.911 people for illegal border crossing, whereas in 2015 the number amounted to 6.980. This was an increase of $42 \%$.

It should be noted, however, that our analysis of the Border Guard's information concerning citizens of the so-called 'migration pressure states' (Syria, Afghanistan, Iraq, Pakistan), who came to Europe on a mass scale in 2015, does not confirm the big influx to Poland. The citizens of Syria, Iraq and Pakistan attempted to enter Poland on the basis of forged or fake documents which authorised them to cross the border (similarly as the citizens of Ukraine, Russia, Belarus or Albania did). They

19 K. Gomółka /2017/, Przeciwdziałanie nielegalnej emigracji na granicy polsko-rosyjskiej w dobie członkostwa Polski w Unii Europejskiej, Annales Universitatis Mariae Curie - Skłodowska Lublin - Polonia, vol. XXIV, no. 2, pp. 75-87; M. Szulecka /20016/, Przejawy nielegalnej migracji w Polsce, Archiwum Kryminologii, vol. XXXVIII, pp. 191-268.

20 M. Perkowska /2016/: Przekroczenie granicy państwa wbrew przepisom jako forma nielegalnej migracji - in: Ochrona praw człowieka w polityce migracyjnej Polski i Unii Europejskiej (W. Pływaczewski, M. Ilnicki, eds.), Olsztyn, p. 199.

21 K. Laskowska /2000/, Przestępczość cudzoziemców w województwie podlaskim, Jurysta, no. 2, p. 19; K. Laskowska /2006/: Rosyjskojęzyczna przestępczość zorganizowana. Studium kryminologiczne, Białystok, pp. 229-230; E.W. Pływaczewski /1999/: Problemy sprawców tzw. rosyjskojęzycznych na tle przestępczości cudzoziemców w Polsce - in: U progu nowych kodyfikacji. Księga pamiątkowa ofiarowana profesorowi Leonowi Tyszkiewiczowi (O. Górniok, ed.), Katowice, pp. 281-282.

22 Ministerstwo Spraw Wewnętrznych i Administracji /2013/: Raport o stanie bezpieczeństwa w Polsce w 2012 roku, Warszawa, p. 121; M. Okólski /2000/, Illegality of International Population Movements in Po-land, International Migration, Special Issue, no. 1, p. 63. 
used air services as they entered into contact with criminal groups in Greece that arranged for them false documents (including Polish passports or ID cards) and tickets for the flights within the Schengen area, including flight tickets to Poland. If we examine the number of nationals from states which are under migratory pressure who were detained for crossing the Polish border illegally in 2015, as opposed to 2014 , an increase can be observed. However, in nominal numbers it was not so considerable if compared to the situation on the other external borders of the European Union.

The migration crisis did not, in any way contribute to the increased illegal migration at the Polish sections of the EU external border. In general, the most interceptions in 2015 took place at the Polish sections of the internal EU border. Foreigners mainly used counterfeit or fraudulent documents. They rarely crossed the state border illegally using violence, threats, deceit or in cooperation with other persons. However, the rise in the number of persons detained for illegally crossing the Polish border in 2015 as compared to 2014 was affected by the increased number of intercepted Ukrainian citizens (2454 of them in 2014 and 3713 in 2015 respectively), but not by the number of detained persons who came from migration risk countries. ${ }^{23}$ Constantly in the analysed time span Ukrainian nationals constituted the largest number of people detected by the Border Guard for illegal crossing followed by Russia, Belarus and Vietnam nationals. It is an inevitable consequence of the fact that these border sections are mostly crossed by the citizens of Poland's neighboring countries. However, it is worth stressing that a significant number of nationals of Moldova, Georgia and Vietnam were detected at the border as well. These people wish to join their communities who have been existing and functioning well in Poland for years thus they use both regular and illegal migration channels to achieve this aim. ${ }^{24}$

Table 4. The number of people apprehended for illegal border by nationality in 2014-2019

\begin{tabular}{|l|c|c|c|c|c|c|}
\hline Nationality & $\mathbf{2 0 1 4}$ & $\mathbf{2 0 1 5}$ & $\mathbf{2 0 1 6}$ & $\mathbf{2 0 1 7}$ & $\mathbf{2 0 1 8}$ & $\mathbf{2 0 1 9}$ \\
\hline Afghanistan & 33 & 36 & 43 & 35 & 55 & 127 \\
\hline Armenia & 43 & 35 & 70 & 75 & 39 & 41 \\
\hline Belarus & 234 & 236 & 247 & 251 & 332 & 192 \\
\hline China & 27 & 36 & 43 & 50 & 50 & 35 \\
\hline Georgia & 168 & 119 & 65 & 43 & 133 & 221 \\
\hline
\end{tabular}

23 M. Perkowska /2019/: Przestępczość cudzoziemców w Polsce od transformacji ustrojowej po kryzys migracyjny - in: Po co nam kryminologia? Ksiega jubileuszowa profesor Ireny Rzeplińskiej (W. Klaus, D. Woźniakowska-Fajst, P. Wiktorska, K. Buczkowski, eds.), Warszawa, p. 379; W. Klaus, M. Lévay, I. Rzeplińska, M. Scheinost /2015/: Refugees and Asylum Seekers in Central, European Countries: Reality, Politics and the Creation of Fear in Societies - in: Refugees and Migrants in Law and Policy Challenges and Opportunities for Global Civic Education (H. Kury, S. Redo, eds.), Springer, p. 481.

24 M. Perkowska /2018/, op.cit., p. 201. 


\begin{tabular}{|l|c|c|c|c|c|c|}
\hline Nationality & 2014 & 2015 & 2016 & 2017 & 2018 & 2019 \\
\hline India & 22 & 45 & 63 & 89 & 98 & 60 \\
\hline Moldova & 31 & 25 & 102 & 88 & 111 & 109 \\
\hline Pakistan & 38 & 58 & 44 & 68 & 44 & 36 \\
\hline Russia & 466 & 613 & 685 & 678 & 461 & 370 \\
\hline Syria & 108 & 175 & 145 & 124 & 118 & 104 \\
\hline Ukraine & 2454 & 3713 & 3981 & 3910 & 2730 & 2759 \\
\hline Vietnam & 210 & 279 & 193 & 146 & 227 & 115 \\
\hline Poland & 323 & 372 & 667 & 657 & n.a. & n.a. \\
\hline Others & 754 & 1238 & 1218 & 1071 & 1126 & 1019 \\
\hline Total & 4911 & 6980 & 7566 & 7285 & 5524 & 5188 \\
\hline
\end{tabular}

Source: the Border Guard Headquarters

It can be concluded from the data on the number of people apprehended for illegal border crossing at the Polish border that it is a marginal phenomenon when compared with the other sections of the EU borders (both external and internal), particularly the sea border sections. It is chiefly due to 'push' factors in the sending states (which recently have been Syria, Eritrea and Afghanistan), whose geographical routes run to Europe through its Southern borders. In addition, Frontex have reported some illegal border crossings between border check points by nationals of Vietnam, Afghanistan and Georgia at the Eastern land section of the EU external border, which reinforces the detections at the Polish section of the EU external border. ${ }^{25}$

\section{CRIMINAL LAW REGULATIONS}

In accordance with the Polish law, illegal crossing of the Polish Republic's borders may constitute a petty offence or an offence in the form of a misdemeanour.

By virtue of Article 49a of the Code of Petty Offences (1971) ${ }^{26}$ illegal crossing of the border of the Republic of Poland constitutes a petty offence hence crossing the border of another country is not punishable. The principles of legal border crossing are prescribed by a number of legal acts such as the Act on Foreigners (2013) ${ }^{27}$ and the Act on the Protection of the State Border (1990) (the Border Act). ${ }^{28}$ Such behaviour is liable to a fine of up to 5000 PLN (app. 1250 EUR). Article 49a of the Code of Petty Offences states: ' $\$ 1$. Whoever crosses the border of the Republic of

25 Ibid., pp. 201-202.

26 Act of 20 May 1971, Code of Petty Offences, Journal of Laws No 12, item 114.

27 Act of 12 December 2013 on foreigners, Journal of Laws 2013 item 1650.

28 Act of 12 October 1990, Borders Act, Journal of Laws 2015, item 930. 
Poland in violation of the relevant regulations shall be subject to a fine. $\$ 2$. Attempt and abetting are punishable. ${ }^{29}$

However, if anyone who illegally crosses the border of the Republic of Poland with the use of violence, threats or deception, or in concert with others is liable to imprisonment for up to three years according to Article 264 (2) of the Penal Code. ${ }^{30}$ Article 264(1) of the Criminal Code states 'Whoever crosses the border of the Republic of Poland in violation of the relevant regulations shall be subject to a fine, the penalty of restriction of liberty or the penalty of deprivation of liberty for up to 2 years' was repealed by the Act of 24 August 2005 amending the Act on Border Guards and some other acts. ${ }^{31}$

This split responsibility results from the fact that in 2004 Polish legislator changed Polish Criminal code and the Article 264(1) of the Criminal Code stating 'Whoever crosses the border of the Republic of Poland in violation of the relevant regulations shall be subject to a fine, the penalty of restriction of liberty or the penalty of deprivation of liberty for up to 2 years' was repealed by the Act of 24 August 2005 amending the Act on Border Guards and some other acts. However, simultaneously, Article 49a was introduced into the Code of Petty Offences.

The legislative, whilst providing reasons for these amendments in the criminal law, stated that the act specified by Article 264(1) of the Criminal Code, border crossing, is a typical violation of an administrative order. It is worth highlighting that the acts falling under Article 264(1) of the Criminal Code are considered petty offences according to the legislation of the Federal Republic of Germany, the Czech Republic and the Slovak Republic. In the context of Poland's accession to the EU it appears appropriate to treat similar violations of law alike. The new regulation serves the purpose of rationalising prosecution and effective application of the principle that punishment is inevitable.

As Bojarski points out, border crossing nowadays is no longer of political character but usually relates to the desire of migrants from poorer countries to find better living conditions. Therefore, their acts cannot, in fact, be treated as serious offences but rather as petty offences. ${ }^{32}$ Moreover, as the national structure of Poland is of a homogenous nature with only a small proportion of foreigners present, immigration to Poland is minimal. Analysing the trends in migration of people applying for international protection, it can be definitely stated that only a few have decided to settle in Poland, with the vast majority treating the country as a transit point. This lack of interest results mainly from the relatively low standards of living in Poland when compared to the so-called 'old' EU Member States, but given that

\footnotetext{
29 Act of 20 May 1971, Code of Petty Offences, Journal of Laws No 12, item 114.

30 Art. 264(2), Act of 6 June 1997, Criminal Code, Journal of Laws 1997 No 88, item 553.

31 Act of 22 April 2005 on amendments of Act on Border Guards and other acts, Journal of Laws No 90, item 757.

32 T. Bojarski /2006/: Kierunki zmian dokonanych w kodeksie karnym z 1997 roku. Charakterystyka ogólna - in: Zmiany w polskim prawie karnym po wejściu w życie kodeksu karnego z 1997 roku (T. Bojarski, K. Nazar, A. Nowosad, M. Szwarczyk, eds.), Lublin, pp. 30-31.
} 
unemployment is falling and salaries are gradually rising, this situation may soon change. ${ }^{33}$

This decriminalisation appears to be a positive change, as illegal border crossing shows a trend towards decline and is closely connected with the migration from the East to the West of Europe. Illegal border crossing does not pose any serious threat either to the Republic of Poland's public or legal order, provided it is not accompanied by other criminal behaviours such as using counterfeited documents, corruption or smuggling goods which is so common at the border. ${ }^{34}$

In addition, experience based on the practice of imposing punishments for illegal border crossing (as a basic offence) has shown that such decriminalisation is needed. The non-custodial punishments prevailed, that is, a fine, restriction of liberty or parole as a means of probation were applied. ${ }^{35}$ Consequently, the fine stipulated under the present code for illegal border crossing serves the purpose of the punishments which had been imposed under the earlier Criminal Code. The practice of imposing non-custodial punishments is particularly justified in the case of foreigners. It is worth underscoring that foreigners detected for illegal border crossing, or who have attempted to do, so constitute 95 per cent of the total number of people apprehended for these reasons since 2008. The fine is a penalty, which can be easily enforced, particularly as far as border criminality is concerned. ${ }^{36}$

Another step taken by the Polish legislative to prevent illegal border crossing was the implementation of the European Council framework decision of 28 November 2002 , on strengthening the penal framework to prevent the facilitation of unauthorised entry, transit and residence ${ }^{37}$ and EU Directive 2002/90/EC defining the facilitation of unauthorised entry, transit and residence. ${ }^{38}$ Based on this the legislative ${ }^{39}$ penalised some actions undertaken for financial and personal benefits which include assisting illegal migration. ${ }^{40}$ In addition, a stricter punishment was introduced for the offence stipulated by virtue of Article 264(3) of the Criminal Code (illegal border crossing arrangements) by determining its limits, that is, subject to deprivation of liberty for a term from six months up to eight years, according to the requirements included in Article 1(3) of the framework decision. ${ }^{41}$ According to Ćwiąkalski, Arti-

33 Polityka migracyjna Polski - stan obecny i postulowane działania, op.cit., p. 68.

34 M. Perkowska /2013/: Prawne i kryminologiczne aspekty dekryminalizacji przestępstwa nielegalnego przekroczenia granicy - in: Granice kryminalizacji i penalizacji (S. Pikulski, M. Romańczuk-Grącka, eds.), Olsztyn, p. 514.

35 M. Perkowska /2013A/: Przestępczość graniczna cudzoziemców, Warszawa, pp. 58-59.

36 M. Perkowska /2013/, op.cit., pp. 514-515.

37 European Council framework decision of 28 November 2002, on strengthening the penal framework to prevent the facilitation of unauthorised entry, transit and residence (2002/946/JHA).

38 Council Directive 2002/90/EC of 28 November 2002 defining the facilitation of unauthorised entry, transit and residence [2002] OJ L328/17.

39 Explanatory memorandum to act changing Criminal Code and other acts, print No 2407, p. 14.

40 Art. 264a (1) of the Criminal Code: enabling and facilitating another person's stay in the Republic of Poland in violation of law.

41 W. Grzeszczyk /2004/, Zmiany w prawie karnym wprowadzone ustawą z dn. 16 kwietnia 2004 r., Prokuratura i Prawo, n. 9, pp. 74-76; C. Nowak /2014/: Wplyw procesów globalizacyjnych na polskie prawo karne, Warszawa, p. 335. 
cle 264a of the Criminal Code was a reaction to an increase in inflow and illegal stays of immigrants, which has resulted from Poland's increased attractiveness and would not be possible without other people's involvement in offering facilitation of illegal entry. Nevertheless, in exceptional cases the possibility of extraordinary mitigating or even waiving the punishment has been stipulated in the article. ${ }^{42}$

According to the legislative, not every case of assisting in illegal migration requires imposition of the punishment stipulated under Article 264a(1) of the Criminal Code. In exceptional cases where the perpetrator has not received any financial benefits, the court might, by virtue of Article 264a(2) of the Criminal Code, mitigate or even waive the punishment. ${ }^{43}$

Article 264(1) of the Criminal Code prescribes the basic offence, which somewhat specifies the provisions of Article 264(2) and (3) of the Criminal Code. Article 264 of the Criminal Code refers to the crossing of the Republic of Poland's borders illegally and assisting in such crossings, whereas Article 264a of the Criminal Code concerns the offence of illegal stays in the territory of the Republic of Poland. According to Pływaczewski, under Article 264a of the Criminal Code it is the state border that receives direct protection against illegal crossing, ${ }^{44}$ whereas the state security is protected indirectly. ${ }^{45}$

As the stricter punishment for the offence stipulated by virtue of Article $264 \$$ $3 \mathrm{CC}$ for the illegal border crossing arrangements was introduced according to the requirements included in Article 1 (3) of the framework decision 2002/946/JHA the author would like to present the types of punishments pronounced to the persons convicted for the arranging of illegal border crossing (art. $264 \$ 3$ of CC) and for those who croseed the border illegally (art. $264 \$ 2$ of CC) from 2009-2018.

The number of convicts under art. $264 \$ 2$ CC was not significant during the analysed period (table 3). The highest number was 681 in 2016 and the lowest 606 in 2018. Its dynamics was stable. The criminal proceedings in those cases do not take too long, approximately less than one year. The offence stated in art. $264 \$ 2$ $\mathrm{CC}$ is punishable only by imprisonment from 1 month up to 3 years. As it is presented in table 3. judges also pronounced monetary penalties and restrictions of liberty. This is possible by the virtue of art. 37a CC, that gives the judge the ability to pronounce fines or restrictions of liberty if the statutory maximum penalty for the offence does not exceed eight years of imprisonment. This concerns also art. $264 \$$ 2 CC. The $26,5 \%$ of convicts were imposed only monetary penalties, $0,5 \%$ - restrictions of liberty and 73\% - imprisonment. However, for 2244 convicts (from 2298) the imprisonment was conditionally suspended. In general, it is possible to suspend conditionally the penalty of imprisonment if it does not exceed one year (previously two years, until 30.06.2015). First it shows that in 2009-2018 more than 98\%

42 Z. Ćwiąkalski /2013/ - in: Kodeks karny. Część szczególna, Tom II. Komentarz do art. 117-277 k.k. (A. Zoll, ed.), Warszawa, p. 1454.

43 P. Gensikowski /2011/: Odstąienie od wymierzenia kary w polskim prawie karnym, Warszawa, pp. $182 \mathrm{ff}$.

44 E. Pływaczewski /2012/ - in: Kodeks karny. Komentarz (M. Filar, ed.), Warszawa, p. 1197.

45 E. Pływaczewski, A. Sakowicz /2010/ - in: Kodeks karny, część szczególna. Tom II. Komentarz do artykułów 222-316 (A. Wąsek and R. Zawłocki, eds.), Warszawa 2010, p. 534. 
of convicts were imposed lenient penalties which in general do not restrict from liberty. The lenient penalties are understandable in this case. There is a general tendency Poland to pronounce non-custodial penalties from one hand. Furthermore foreigners who were found guilty for the illegal border crossing are obliged to leave Polish territory on the ground of art. 302 (1)(1) of Act on Foreigners, as he is on Polish territory without valid visa or any other permission.

Table 3. Penalties pronounced for violation of art. $264 \$ 2$ of Polish Criminal Code in 2014-2018

\begin{tabular}{|c|c|c|c|c|c|c|}
\hline Year & $\stackrel{\varpi}{\stackrel{\sim}{~}}$ & $\stackrel{n}{\stackrel{n}{\sim}}$ & $\stackrel{\circ}{\stackrel{\sim}{\sim}}$ & 공 & $\stackrel{\infty}{\stackrel{\sim}{\sim}}$ & స్్ㅇ \\
\hline Number of convicts & 610 & 641 & 681 & 610 & 606 & 3148 \\
\hline Monetary penalty & 78 & 97 & 208 & 179 & 273 & 835 \\
\hline Suspended monetary penalty & 7 & 9 & 5 & 0 & 0 & 21 \\
\hline Limitation of liberty (social works) & 2 & 1 & 3 & 7 & 2 & 15 \\
\hline Imprisoment & 530 & 543 & 470 & 424 & 331 & 2298 \\
\hline Imprisonment without suspention & 8 & 8 & 2 & 13 & 23 & 54 \\
\hline Suspended imprisonment & 522 & 535 & 468 & 411 & 308 & 2244 \\
\hline Imprisonment with monetary penalty & 82 & 45 & 46 & 40 & 65 & 278 \\
\hline Suspended imprisonment with monetary penalty & 82 & 44 & 46 & 40 & 51 & 263 \\
\hline
\end{tabular}

Source: Ministry of Justice https://isws.ms.gov.pl/pl/baza-statystyczna/opracowania-wieloletnie/

Table 4. Penalties pronounced for violation of art. $264 \$ 3$ of Polish Criminal Code in 2014-2018

\begin{tabular}{|c|c|c|c|c|c|c|}
\hline Year & 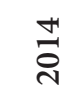 & $\frac{n}{0}$ & $\frac{0}{0}$ & $\frac{\curvearrowright}{\partial}$ & $\stackrel{\infty}{\frac{\infty}{8}}$ & 퓸 \\
\hline Number of convicts & 77 & 100 & 113 & 117 & 149 & 556 \\
\hline Monetary penalty & 1 & 1 & 11 & 14 & 34 & 61 \\
\hline Suspended monetary penalty & 0 & 1 & 0 & 0 & 0 & 1 \\
\hline Limitation of liberty (social works) & 0 & 1 & 4 & 8 & 8 & 21 \\
\hline Imprisoment & 76 & 98 & 98 & 95 & 106 & 473 \\
\hline Imprisonment without suspention & 10 & 10 & 7 & 11 & 18 & 56 \\
\hline Suspended imprisonment & 66 & 88 & 91 & 84 & 88 & 417 \\
\hline Imprisonment with monetary penalty & 53 & 77 & 49 & 73 & 17 & 269 \\
\hline Suspended Imprisonment with monetary penalty & 51 & 68 & 46 & 67 & 16 & 248 \\
\hline
\end{tabular}

Source: Ministry of Justice https://isws.ms.gov.pl/pl/baza-statystyczna/opracowania-wieloletnie/ 
The number of convicts under art. $264 \$ 3 \mathrm{CC}$ was not significant during the analysed period (table 4). The highest number was 149 in 2018 and the lowest 65 in 2016. However it is hard to analyse any trends of dynamics as the criminal procedure takes time. Court proceedings can be long and the conviction can be distant from the prohibited act. The offence stated in art. $264 \$ 3 \mathrm{CC}$ is punishable only by imprisonment from 6 months up to 8 years. Still as it is presented in table 4 . judges also pronounced monetary penalties and restrictions of liberty. This is possible by the virtue of art. 37 a CC mentioned above. Only $4 \%$ of convicts were imposed monetary penalties, $1,5 \%$ - restrictions of liberty and 95,5\% - imprisonment. However, for 417 convicts (from 473) the imprisonment was conditionally suspended. First it shows that in 2009-2018 more than $85 \%$ of convicts were imposed lenient penalties which in general do not restrict from liberty. Secondly it opens the question on the necessity to implement the maximum penalty of eight years on the basis of framework decision 2002/946/JHA into Polish criminal code for the assistance of illegal border crossing. The practice of Polish jurisprudence reveals that imprisonment penalties pronounced under art. $264 \$ 3 \mathrm{CC}$ are not high. It is also necessary to state that they are very low. The maximum penalty is up to eight years while judges mostly pronounce one year (eventually 2 years). What is more the detailed analysis revealed that in the period 2009-2018 the penalty exceeding five years of imprisonment was never imposed by the virtue of art. $264 \$ 3$ CC. Merely in 15 cases judges pronounced penalties exceeding three years but not exceeding 5 years of imprisonment. This means that the aggravation of maximum penalty, that was influenced by EU law, was useless. The judges, by the use of directives of passing the sentence, do not find the factors to pronounce a severe penalty exceeding five years of imprisonment. In the author's opinion it is more important to deprive the offenders of the profits gained for the arrangement of illegal border crossing than placing them into prison. This kind of activity halts the profit, even if it is not stipulated in art. $264 \S 3$ CC. ${ }^{46}$

\section{CONCLUSION}

Taking into consideration the geopolitical location of Poland (together with its neighbors) on the map of Europe one could undoubtedly state that it is situated on the migration routes from Eastern to Western Europe. They lead mainly from Asia and from the Middle East countries. Poland's membership in the European Union and its status in the Schengen area should also affect the inflow and through-flow of legal and illegal migrants, especially through its eastern border which is also the EU external border. The analysis of the Border Guard data on the number of persons apprehended for crossing the border illegally leads to other conclusions. In comparison to other sections of the European Union's internal borders, the phenomenon on the Polish borders may be considered as a marginal one. However illegal border crossings do occur, with the biggest numbers of detained Ukrainians. The dynamics

46 M. Perkowska /2020/, The impact of the European law on Polish criminal law dealing with illegal migration, Zeszyty Naukowe UKSW, forthcoming. 
of illegal border crossing is mostly influenced by the political and military situation in the Ukraine.

The legal reaction to this phenomenon refers to the criminal responsibility for illegal border crossing but also for the arrangement of illegal border crossing. The penal policy towards foreigners who crossed Polish border illegally is lenient. This results from the low maximum penalty that is 3 years of imprisonment. Furthermore, there is a general tendency Poland to pronounce non-custodial penalties, especially for the foreigners who in this case are obliged to leave Polish territory, as they do not have legal ground for stay.

The organising illegal border crossing is subject to an imprisonment for a term of between 6 months to 8 years. In accordance with Article $264 \$ 3$ of the Penal Code, Polish courts impose custodial sentences but mainly a suspended one. Custodial sentences imposed may give rise to some doubts, mainly due to the high risk of imprisonment of up to 8 years, especially taking into account the fact that both lower and upper limits were increased (from 3 to 6 months and from 5 to 8 years respectively). However, increasing the upper limit turned out to be a fiction in penal practice as the courts do not impose severe penalties. Also, in case of this offence judges mostly pronounce non-custodial penalties as they do not find the necessity to pronounce severe penalties in their discretion.

\section{REFERENCES}

Bojarski T. /2006/: Kierunki zmian dokonanych w kodeksie karnym z 1997 roku. Charakterystyka ogólna - in: Zmiany w polskim prawie karnym po wejściu $w$ życie kodeksu karnego z 1997 roku (T. Bojarski, K. Nazar, A. Nowosad, M. Szwarczyk, eds.), Lublin.

Ćwiąkalski Z. /2013/ - in: Kodeks karny. Część szczególna, Tom II. Komentarz do art. 117277 k.k. (A. Zoll, ed.), Warszawa 2013.

Europol /2016/: Migrant smuggling in the EU.

Europol /2017/: European Union serious and organised crime threat assessment. Crime in the age of technology.

Frontex /2015/: Risk Analysis for 2014, Warsaw.

Frontex /2016/: Risk Analysis for 2015, Warsaw.

Frontex /2019/: Risk Analysis for 2018, Warsaw.

Gensikowski P. /2011/: Odstapienie od wymierzenia kary w polskim prawie karnym, Warszawa.

Gomółka K. /2017/, Przeciwdziałanie nielegalnej emigracji na granicy polsko-rosyjskiej w dobie członkostwa Polski w Unii Europejskiej, Annales Universitatis Mariae Curie Skłodowska Lublin - Polonia, vol. XXIV, no. 2.

Grzeszczyk W. /2004/, Zmiany w prawie karnym wprowadzone ustawą z dn. 16 kwietnia 2004 r., Prokuratura i Prawo, n. 9.

Klaus W., Lévay M., Rzeplińska I., Scheinost M. /2015/: Refugees and Asylum Seekers in Central, European Countries: Reality, Politics and the Creation of Fear in Societies - in: Refugees and Migrants in Law and Policy Challenges and Opportunities for Global Civic Education (H. Kury, S. Redo, eds.), Springer. 
von Lampe K. /2005/: Organised Crime in Europe - in: Handbook of Transnational Crime and Justice (P. Reichel, ed.), London, New Dehli.

Laskowska K. /2000/, Przestępczość cudzoziemców w województwie podlaskim, Jurysta, no. 2.

Laskowska K. /2006/: Rosyjskojęzyczna przestępczość zorganizowana. Studium kryminologiczne, Białystok.

Ministerstwo Spraw Wewnętrznych i Administracji /2012/: Raport o stanie bezpieczeństwa w Polsce w 2011 roku, Warszawa.

Ministerstwo Spraw Wewnętrznych i Administracji /2013/: Raport o stanie bezpieczeństwa w Polsce w 2012 roku, Warszawa.

Ministerstwo Spraw Wewnętrznych i Administracji /2014/: Raport o stanie bezpieczeństwa w Polsce w 2013.

Ministerstwo Spraw Wewnętrznych i Administracji /2015/: Raport o stanie bezpieczeństwa w Polsce w 2014 roku, Warszawa.

Ministerstwo Spraw Wewnętrznych i Administracji /2016/: Raport o stanie bezpieczeństwa w Polsce w 2015 roku, Warszawa.

Ministerstwo Spraw Wewnętrznych i Administracji Departament Polityki Migracyjnej 12011/: Polityka Migracyjna Polski - stan obecny i postulowane działania, Warszawa.

Nowak C. /2014/: Wpływ procesów globalizacyjnych na polskie prawo karne, Warszawa.

Okólski M. /2000/, Illegality of International Population Movements in Poland, International Migration, Special Issue, no. 1.

Perkowska M. /2013/: Prawne i kryminologiczne aspekty dekryminalizacji przestępstwa nielegalnego przekroczenia granicy - in: Granice kryminalizacji i penalizacji (S. Pikulski, M. Romańczuk-Grącka, eds.), Olsztyn.

Perkowska M. /2013A/: Przestępczość graniczna cudzoziemców, Warszawa.

Perkowska M. /2016/: Przekroczenie granicy państwa wbrew przepisom jako forma nielegalnej migracji - in: Ochrona praw człowieka w polityce migracyjnej Polski $i$ Unii Europejskiej (W. Pływaczewski, M. Ilnicki, eds.), Olsztyn.

Perkowska M. /2017/: Charakterystyka przestępczości granicznej cudzoziemców w Polsce na podstawie wyników badań akt spraw karnych - in: Przestępczość cudzoziemców. Aspekty prawne, kryminologiczne i praktyczne (W. Klaus, K. Laskowska, I. Rzeplińska, eds.), Warszawa.

Perkowska M. /2018/: The Impact of the Migration Crisis on Polish Immigration and Criminal Law - in: Irregular Migration as a Challenge for Democracy (E. Kużelewska, A. Weatherburn, D. Kloza, eds.), Cambridge-Antwerp-Portland.

Perkowska M. /2019/: Przestępczość cudzoziemców w Polsce od transformacji ustrojowej po kryzys migracyjny - in: Po co nam kryminologia? Księga jubileuszowa profesor Ireny Rzeplińskiej (W. Klaus, D. Woźniakowska-Fajst, P. Wiktorska, K. Buczkowski, eds.), Warszawa.

Perkowska M. /2020/, The impact of the European law on Polish criminal law dealing with illegal migration, Zeszyty Naukowe UKSW, forthcoming.

Pływaczewski E. /2012/ - in: Kodeks karny. Komentarz (M. Filar, ed.), Warszawa.

Pływaczewski E., Sakowicz A. /2010/ - in: Kodeks karny, część szczególna. Tom II. Komentarz do artykułów 222-316 (A. Wąsek and R. Zawłocki, eds.), Warszawa 2010.

Pływaczewski E.W. /1999/: Problemy sprawców tzw. rosyjskojęzycznych na tle przestępczości cudzoziemców w Polsce - in: U progu nowych kodyfikacji. Księga pamiątkowa ofiarowana profesorowi Leonowi Tyszkiewiczowi (O. Górniok, ed.), Katowice. 
Szulecka M. /20016/, Przejawy nielegalnej migracji w Polsce, Archiwum Kryminologii, vol. XXXVIII.

UNODC /2016/: Smuggling of migrants from Pakistan. Reasons, routes and risks.

\section{Magdalena Perkowska*}

\section{ODGOVOR POLJSKE NA ILEGALNI PRALAZAK DRŽAVNE GRANICE}

Autorka u radu nastoji da prikaže izazove sa kojima se Poljska suočava zbog problema nedozvoljenog prelaska državnih granica.

Prvi deo rada prikazuje podatke o broju ilegalnih prelazaka granica Poljske u poslednjih šest godina. Iako je Poljska članica Evropske unije, a istovremeno je i u tzv. Šengenskoj zoni, analizirajući zvanične podatke i dovodeći ih u vezu sa faktorima koji su u pomenutom periodu doveli do povećanih migracija ljudi (uključujući migrantsku krizu, sukob u Ukrajini), autorka zaključuje da se, iz perspektive Poljske, ipak radi o marginalnoj pojavi u poređenju sa problemima sa kojima se suočavaju druge države članice Evropske unije. Jedan od glavnih razloga leži u činjenici da glavne rute za ulazak u evropske zemlje i dalje ostaju južne države.

Drugi deo rada prikazuje zakonsku regulativu posvećenu ilegalnom prelasku državnih granica, pre svega iz perspektive krivičnog zakonodavstva, kao i podatke o broju osuđenih lica za krivična dela povezana sa ovim fenomenom. Kaznena politika u ovoj oblasti može se oceniti kao blaga - najstroža kazna koja se može izreći je tri godine zatvora, a uočava se tendencija izricanja kazni koje ne podrazumevaju lišenje slobode. Sa druge strane, za organizovanje ilegalnog prelaska granice moguće je izreći kaznu zatvora u rasponu od šest meseci do osam godina. Međutim, čak i u ovom slučaju, sudovi su prevashodno izricali kazne bez lišenja slobode.

Ključne reči: ilegalne migracije, ilegalni prelazak državne granice, kriminalna politika.

* Docent, Pravni fakultet, Univerzitet u Bjalistoku, m.perkowska@uwb.edu.pl. 